\title{
THE EFFECTS OF DRAMA TRAINING ON INTERPERSONAL MANAGEMENT SKILL OF MANAGERS ${ }^{1}$
}

Recep İbrahim PINAR ${ }^{2}$

Özgür KÖKALAN ${ }^{3}$
Received Date (Başvuru Tarihi): 14/04/2017

Accepted Date (Kabul Tarihi): 06/08/2017

Published Date (Yayın Tarihi): 15/09/2017

\begin{abstract}
The main purpose of this study is to examine the effects of drama training on interpersonal management skill of managers. An experimental study was conducted in this research. The participants of the study were 20 managers divided into 10 as an experimental group and 10 as a control group. The drama training was given to participants of the experimental group by a specialist trainer and then the effects of this training were analyzed by quantitative research methods. In the quantitative research, a questionnaire that was used to determine the interpersonal management skill of managers was conducted before the training for both the participants of the experimental group and control group. In order to determine the effects of drama training, the same questionnaire was again conducted to all participants after the training and the effects of training on the participants of the experimental group were analyzed by a quantitative software programcalled as SPSS 20.0. According to research results, it was proved that the interpersonal management skill was developed becau se of drama training.
\end{abstract}

Keywords: Drama Training, The Interpersonal Management Skill, Empathy

JEL Codes: 121, M10, Y4

\section{DRAMA EĞITTIMININ YÖNETICILLERIN BEŞERİ İLIŞKILLER YETENEĞİ ÜZERINE ETKILERI}

ÖZ

Drama eğitiminin yöneticilerin beşeri ilişkiler yeteneği üzerindeki etkisinin incelenmesi bu araştırmanın temel amacını oluşturmaktadır. Araştırmada deney kontrol grubu kullanılmı ştır. Araştırmada 10 'u deney grubuna, 10 'u kontrol grubuna dâhil olan toplam 20 yönetici, örneklem olarak seçilmiştir. Deney grubuna dâhil olan katılımcılara uzman bir ĕgitmenle drama ĕgitimi verilmiş ve daha sonra ĕgitimin etkileri nicel yollarla değerlendirilmiştir. Nicel araştırma kapsamında hem deney hem de kontrol grubuna dâhil olan katılımcılara eğitiminin öncesinde yöneticilerin beşeri ilişkiler yeteneğini belirlemek için anket uygulanmiştır. Aynı anket eğitiminin sonrasında tüm katılımcılara bir kere daha uygulanmış ve eğitimin deney grubuna dâhil olan katılımcılar üzerindeki etkileri bir nicel yazılım programı olan SPSS 20.0 ile tespit edilmiştir. Yapılan nicel araştırmaların sonucunda ĕgitimi alan katılımcıların beşeri ilişkiler yeteneğinin geliştiğ i saptanmıştır.

Anahtar Kelimeler: Drama Ĕ̆itimi, Beşeri İlişkiler Yeteneği, Empati Jel Kodları: $\quad$ I21, M10, Y4

\footnotetext{
1 This article is written from the doctoral dissertation, that is called as "The effects of drama education on managers' interpersonal skills and conceptual skills", prepared by Özgür Kökalan for the doctoral program of Business Management and Organization at Istanbul University in 2010.

${ }^{2}$ Prof. Dr. İstanbul University, School of Business, The Department of Business Administration, ipinar@istanbul.edu.tr

${ }^{3}$ Ass. Prof. Dr. İst anbul Sabahattin Zaim University, The Faculty of Business and Management Sciences, The Department of Business Administration, ozgur.kokalan@izu.edu.tr
} 


\section{INTRODUCTION}

As of early 1900, the management concept has been investigated more and more, and has arrived in our present day after many significant changes. The classical management, which defended that the true, universal and absolute knowledge existed, has been replaced by the postmodern management, which claimed that there was not true, universal and absolute knowledge.

This evolution in the management concept has also caused some changes in the roles and skills of the managers. On the one hand, the classical management, which defended that the absolute and universal knowledge existed, claimed that the technical skill was the most important skill for a manager; the concept of interpersonal management skill gained importance as of 1930s; and in 1960s, the conceptual skill became the indispensable ability especially for senior managers.

These changes in the management skills also brought some changes in the training techniques provided to managers. At first, the trainings were intended to develop merely the technical skills of managers; however, in time, new training techniques were developed to strengthen the interpersonal management skill and conceptual skill of the managers. Today, managers are trained both with the former techniques and with the new ones in a multidimensional manner. However, it is observed that the training materials developed so far have been generally formed according to rational parameters, in other words, they are designed according to the universal and absolute knowledge, which was originally defended by the classical management movement.

Right at this point, it is clear that there is a need for a new training technique that is not solely dependent on rational parameters with all aspects for the purpose of developing the interpersonal management skill and conceptual skill of managers. In this study, the effects of drama training on interpersonal management skill of managers have been examined.

Drama training was applied to a group of 10 managers with the help of a specialist trainer for 10 weeks, and the results were evaluated with a quantitative research method. The "Social Skills Scale" was applied to the participants within the experimental and control groups for the quantitative study in order to determine the interpersonal management skill levels and to analyze the differences between them, both before and after the training. At the end of the training, it was determined that the drama training developed the interpersonal management skill of managers. 


\section{THEORETICAL FRAMEWORK}

\subsection{Managerial Skills And Manager Training}

Managers have three basic skills, which are named as technical skills, interpersonal management skill and conceptual skill (Koçel, 2015). Technical skills may be explained briefly as having the knowledge about the works that are under a manager's responsibility (Koçel, 2015). Interpersonal management skill is expressed as the skill of a manager in directing her/his employees to work with enthusiasm and in establishing good relations with the senior and lower-level management (Mirze, 2016). The last skill that is necessary for a manager is the conceptual skill, which is the ability understanding the relations between the units in the organization and see the organization as a whole (Mirze, 2016).

When the evolutional development of the management concept is considered, it is observed that there is an assumption in the classical management claiming that the stereotyped notion and rationality may only be ensured with technical skill. For this reason, in the management concept in this period, it is observed that technical skills are emphasized, which means managers should have the "skills to use the tools and techniques that are required by the job; and the knowledge, skills, and experience that are needed to perform the job" (Baransel, 1976; Daft, 2015)

While the technical skills were considered as the basic and most important skills of a manager during the classical management period; in the neo-classical management, the interpersonal management skill, which are also named as "the skill of establishing relations with the individuals at working place", has been seen the inevitable skill of managers (Baransel, 1976; Daft, 2015).

The studies conducted after the emergence of the modern management concept caused that the management concept had an important evolution. Until then, the understanding which claimed that organizations were "closed" (mechanical) left its place to the thinking claiming organizations were influenced by environmental factors and were "open" (organic) structures for these factors. This convertion made unavoidable for the managers to understand environmental factors and consider them in a holistic manner, in other words, they had to acquire the conceptual skill (Baransel, 1976). Today, these three skills are accepted as the basic skills required for managers (Koçel, 2015; Daft, 2015)

Organizations developed several training programs that intended to develop the skills of managers in order to be more productive and more active. The training techniques used in 
organizations to train managers may be examined throughout historical process. They may also be examined as traditional training techniques and modern training techniques. In this study, the traditional and modern training techniques, which were suggested by noe (2009), have been taken as in a manner independent from the historical process. According to this classification, it is possible to categorize the training techniques as follows:

Traditional training methods

A1) Off The Job Training Methods

- Narrative Method

- Audiovisual Methods

A2) On The Job Tranining Methods

- Apprenticeship

- Case Study

- Simulation Method

- Business Game Method

- Modeling Method

-Outdoor \& Adventure Method

- Role Playing Training Method

B) Modern Training Methods

- Multimedia Training

- Computer Based Training

- Distance Education (Noe, 2009).

Although these training methods aimed to develop, the three skills together, the techniques that develop the interpersonal management skill and conceptual skill for senior-level managers have been cared for more in recent years (Noe, 2009; Daft, 2015; Koçel, 2015).

In this study, the effects of drama training on the interpersonal management skill of the managers are investigated. When the literature is reviewed, it is observed that drama training is matched with role-playing training. Role-playing training is a part of drama training. For this reason, it is necessary to define drama training as the first step. 


\subsection{Drama Training}

The drama concept does not have a full counterpart in the English language. In etymological terms, the concept has been derived from the Greek word "Dran", which meant "movement" (Güner, 2005). While defined the drama concept as the "Re-animation of a topic, event, an action or an emotion; in one sense, an imaginary play" (Dirim, 1999); üstünda ğ defined this concept as "an education method to acquire cognitive behaviors, emotional properties and psychomotor abilities" (Üstündağ, 1998). Üstündağ emphasized that drama should be defined as a discipline which aimed the training of the emotions and which ensured that the individual had holistic understanding and the ability to define, explain and control an experienced situation (Üstündağ, 1998). San, on the other hand, defined the drama concept as "a unique way to make sense of life, which ensures personal development" (San, 1991).

Today, it is observed that the definitions on drama concept are more comprehensive. However, it is necessary to care for certain points while defining the drama concept. First of all, drama is considered as a training technique that is specific to theater because it is mostly used in theater training. Although the techniques known as theater techniques are used in drama training, it should never be considered as acting or performing a theatrical act (Güner, 2005). Another important aspect is that drama is confused with plays. Many people consider drama as an identical concept with play. There is play in the core of drama; however, drama should not be understood as mere play. Drama carries many elements which are also included by plays to some extent, and these elements are, seriousness, being not the real life situation, voluntary participation, joy, freedom, life rehearsal, imitation, creativity, discharge, tension, being conducted for a certain purpose, being performed in a certain place and time, and being dependent on certain rules. However, the most important elements of play, which are the winning and leading concepts, do not comply with drama. Plays are made use of during drama trainings; however drama may not be defined as a play; it is something more than a play and covers the play as well. As a last item, it is possible to define drama as a discipline on its own that establishes relations between disciplines (Güner, 2005). In the light of these definitions, it is possible to say that drama is a discipline and a training method that may be used in all areas of life not only in theatre, to influence the cognitive, emotional and psychomotor abilities of a person in a positive.

Drama is extremely important in the personal development of an individual. For the first thing, drama is prepared in a fictional medium, the individual reflects the experience obtained in fictional medium to the real life. The participant senses drama as if it is real, and experiences 
real feelings. When considered in this context, the reality and the fiction are merged in drama. The participants enter fictional situations from reality and vice-versa all the time during the drama training (Okvuran, 2001; Akyol, 2003). The individuals that take part in drama training learn situations, events and relations by discovering during their trainings. The participants use their knowledge and experiences in the real world to create an imaginary world in drama, and learn how to examine the events and relations when they define the situations and roles they designed in drama (O'Neill \& Lambert, 1982; Akyol, 2003). In other words, drama is a bridge between the fictional world and the real world. Drama reinforces the development of the existing creativity of the individuals, develops their imaginations making them acquire skills on their developmental properties, and guides them for multi-dimensional development. It is beneficial for individual development. With drama, it is ensured that individuals see their environment and themselves in a deep and universal dimension not merely in a superficial manner (Başkaya, 2000; Akyol, 2003; Gönen \& Uyar Dalkılıç, 2010).

Spolin (1999) claims that the individual may only see her/his environment in a deeper manner after s/he performs three stages. According to spolin (1999), the individual must firstly discover himself/herself in order to obtain these skills, in other words, s/he must know her/his perceptional limits, and then discover her/his close surroundings; and as the last item, s/he must discover the general environment and the whole universe. (Spolin, 1999). Spolin says that an individual may overcome these three stages alone with the help of drama. The drama technique is a special training technique designed to perform these three stages. The role playing technique, on the other hand, is a training method given place in the second stage (Spolin, 1999).

\subsection{The Effects Of Drama Training On Organizations And Managers}

Especially in the past two decades, there have been many studies conducted to measure the efficiency of training with drama by scientists dealing with the business management field (Baron, Harris et.al, 2001; Beckwith, 2003; Corsun, Young, McManus, \& Erdem, 2006; Cunha, Kamoche, \& Cunda, 1999; Fisk \& Grove, 1996; Gardner \& Avolio, 1998; Gibb, 2004; Goddard, 1999; Goodwin, 1996; Grahan-Hill \& Grimes, 2001; Harris \& Spiro, 1981; Harvey, 2001; Higgs, 1993; Higgs, 1993; Hsu, 1989; Häpfl \& Schreyägg, 2004; Mayer, 2001; Moshavi, 2001; O'Neill \& Lambert, 1982; Pearce, 2006; Pearce \& Jackson,2006; Vera, 2004; Williams \& Anderson, 2005)

When the literature is reviewed, it is observed that mostly the "Creative Drama" - with its more common name "Role Playing"- type is used as the subject of many studies in the 
business management literature in the early periods when drama technique was first used. Almost all of these studies were conducted to examine the effects of drama training on the sales of businesses, and they dealt generally with the marketing functions of the businesses. Almost in all of these studies, it was proven that drama training had positive effects on sales (Fisk \& Grove, 1996; Goodwin, 1996; Pearce, 2006; Pearce \& Jackson,2006; Williams \& Anderson, 2005).

It was no surprise that scientists firstly investigated the effects of drama training on the financial status of businesses, which is also the case in many other studies. Unfortunately, these studies caused that the limits of this technique were drawn in an extremely narrow manner in the early periods. In these studies, drama was only considered as a training technique that was used to make the employees (the individuals) to express themselves in a more accurate manner (Fisk \& Grove, 1996; Goodwin, 1996; Pearce, 2006; Pearce \& Jackson,2006; Williams \& Anderson, 2005). As a result of these studies aimed to ensure that drama is conducted to make employees use their body languages in a more efficient and accurate manner by developing their gestures and mimes, it was observed and reported in almost all of these studies that drama had positive influences in the communication and interpersonal relations.

The direct effects of drama on the employees of the businesses, and its indirect effects on sales and financial status of businesses caused that the interest in drama training technique increased even more. This training technique, which became more and more popular with each passing day, caused that scientists conducted studies that measured the efficiency of drama training on various subjects since the second half of 1990s until our present day. With these studies, the effects of drama training on almost all business functions were examined in a more detailed manner; Beckwith, 2003; Corsun, Young, McManus, \& Erdem, 2006; Cunha, Kamoche, \& Cunda, 1999; Fisk \& Grove, 1996; Gardner \& Avolio, 1998; Gibb, 2004; Goddard, 1999; Goodwin, 1996; Grahan-Hill \& Grimes, 2001; Harris \& Spiro, 1981; Harvey, 2001; Higgs, 1993; Higgs, 1993; Hsu, 1989; Häpfl \& Schreyägg, 2004; Mayer, 2001; Moshavi, 2001; O'Neill \& Lambert, 1982; Pearce, 2006; Pearce \& Jackson,2006; Vera, 2004; Williams \& Anderson, 2005)

Many studies have been conducted to examine the effects of drama training on the interpersonal management skill of the managers. In all of these studies, it was determined that drama training had developed human relations (Kara \& Çam, 2007; Okvuran, 2001; Önalan Akfirat, 2004; Önder, 2016). The previous studies show differences in terms of the technique used, although they were conducted for similar purposes with this study. Firstly, in the present 
study, the drama training has been dealt with as a whole; it does not include mere role playing. The training is more comprehensive when compared with the training methods used in the other studies. In addition, the sub-dimensions of interpersonal management (social) skill, which were not included in the other studies, have been included in this study in detail.

\section{RESEARCH METHODOLOGY}

\subsection{The Purpose Of The Study}

The study aims to determine the effects of drama training on the interpersonal management skill of managers.

\subsection{The Scope Of The Study}

The 20 participants, who were selected for the study, were determined from among the managers who were assigned as managers in medical companies located in Istanbul. In determining the participants for the study, the "participant information form", which was developed by the author of the study, was distributed to 30 managers in the company, and 10 managers were included in the study as the experimental group, and 10 managers were included in the study as the control group. All the analyses conducted in the study were made in the light of the data that were obtained from these managers. Detailed information on the managers will be provided in the last section of the study.

\subsection{Data Collection Tools}

The data obtained in the study were analyzed by using quantitative research techniques. The scale used in this part of the study was applied to all participants both in the experimental group and in the control group. After this process, the participants were compared with themselves and with the other participants, and the effects of drama training on interpersonal management skill of the managers were determined. Some academicians consider that apply the same scale twice, has some kind of drawbacks. However, it is defended that this drawback is mostly eliminated with the training period and the number of the variables. The author of the study considers that using the same scale does not have any drawbacks because the drama training lasted for 10 weeks, in other words, the duration was long, and the number of the variables in the study was more.

There are many scales in the literature to measure the interpersonal management skill. "Wolpe-Lazarus Entrepreneurship Scale" (1966), "Ratrus Assertiveness Scale" (1977), "Test

for Recognizing Facial Expressions" (1987), "Personal Relations Scale” (1986) may be given 
as the examples for these types of scales. In this study, Riggio's (1989) "Social Skills Scale" (SSS) was used (Yüksel, 2004). SSS was developed by Riggio in 1986, was reorganized in 1989 and has been used ever since. SSS was prepared for the purpose of measuring the basic social skills of an individual (Yüksel, 2004).

SSS consists of 90 items that measure six different social skills areas, and is an important tool that covers all the sub-fields of social skills and helps us measure the total social skill levels of individuals. It is impossible to give all items in SSS, hence sample items for each sub scale are given in Table 1.

Table 1: Sample Items From Each Of The Social Skill Inventory

\begin{tabular}{|c|c|}
\hline Emotional Expressivity & $\begin{array}{l}\text { - } \quad \text { When I get depressed, I tend to bring down those around me. } \\
\text { - } \quad \text { I have been told that I have "expressive" eyes. } \\
\text { - } \quad \text { Quite often I tend to be the "life of the party." }\end{array}$ \\
\hline Emotional Sensitivity & $\begin{array}{l}\text { - It is nearly impossible for people to hide their true feelings from me. } \\
\text { - } \quad \text { At parties I can instantly tell when someone is interested in me. } \\
\text { - } \quad \text { People often tell me that } 1 \text { am a sensitive and understanding person. }\end{array}$ \\
\hline Emotional Control & $\begin{array}{l}\text { - I am able to conceal my true feelings from just about anyone. } \\
\text { - } \quad \text { I am very good at maintaining a calm exterior, even when upset. } \\
\text { - When I am really not enjoying my self at some social function, I can still make } \\
\text { my self look as if I am having a good time. }\end{array}$ \\
\hline Social Expressivity & $\begin{array}{l}\text { - At parties i enjoy speaking to a great number of different people. } \\
\text { - } \quad \text { When in discussions, I find my self doing a large share of the talking. } \\
\text { - } \quad \text { I usually take the initiative and introduce my self to strangers. }\end{array}$ \\
\hline Social Sensitivity & $\begin{array}{l}\text { - Sometimes I think that I take things that other people say to me too personally. } \\
\text { - I often worry that people will misinterpret something that I have said to them. } \\
\text { - While growing up, my parents were always stressing the importance of good } \\
\text { manners. }\end{array}$ \\
\hline Social Control & $\begin{array}{l}\text { - I find it very easy to play different roles at different times. } \\
\text { - When in a group of friends, I am often spokesperson for the group. } \\
\text { - I can fit in with all ty pes of people, y oung and old, rich and poor. }\end{array}$ \\
\hline
\end{tabular}

Source: Riggio, R. E. “Assessment Of Basic Social Skills”, (1986, Journal OfPersonality And Social Psychology, Vol.51, No.3, S. 652). Copyright 1986 By The American Psychological Association, Inc.

The sub-scales that are included in the SSS are as follows:
1. Emotional expressivity
2. Emotional sensitivity
3. Emotional control
4. Social expressivity
5. Social sensitivity
6. Social control (Riggio, 1989).

SSS covers six sub-scales at two levels, which are the emotional and social levels intended to measure social communication skills. "expressivity", "sensitivity", and "control" are evaluated with each level in sss. "expressivity" refers to the ability of sending messages to 
others. "sensitivity" refers to the ability of interpreting the messages received from the other individuals, and "control" refers to the ability of organizing the communication process in various social situations by the individuals. The sub-scales are dealt with in detail in the following section (Riggio, 1986)

1) Emotional expressivity (EE) sub-scale measures the non-verbal communication skills of an individual, especially the ability to send emotional messages. This sub-scale may also measure the non-verbal narration side of the inclinations in interpersonal relations. This sub-scale also measures the ability of the individual to express emotional situations. According to Riggio, individuals who have emotional expressivity are lively and joyful. They may impress other individuals with these characteristics (Riggio, 1986; Yüksel, 2004; Riggio \& Reichard, 2008; Kalafat \&Kincal, 2008).

2) Emotional sensitivity (ES) sub-scale measures the ability of individuals to receive and analyze non-verbal messages of the others. The individuals who are sensitive in emotional terms analyze the non-verbal emotional messages of the others. Empathy skill developed at an extreme level in such individuals. The individuals with developed emotional sensitivity are defined as the individuals that are sympathetic, assertive, stressful, and audacious and free (Riggio, 1986; Yüksel, 2004; Riggio \& Reichard, 2008; Kalafat \&Kincal, 2008).

3) Emotional control (EC) sub-scale measures the ability of individuals to organize and control emotional and non-verbal reactions. Emotional control covers the abilities to merge and hide certain emotions in a skillful manner behind a mask. Individuals with emotional control may control themselves. The self-respect of such individuals is high (Riggio, 1986; Yüksel, 2004; Riggio \& Reichard, 2008; Kalafat \&Kincal, 2008).

4) Social expressivity (SE) sub-scale measures the skills of individuals in verbal expression, establishing communications with each other and joining conversation. Individuals who have social expressivity are people who are lively, social, consistent in emotional terms, and are extrovert. They have the ability of starting any conversation or sustaining these conversations (Riggio, 1986; Yüksel, 2004; Riggio \& Reichard, 2008; Kalafat \&Kincal, 2008).

5) Social sensitivity (SS) sub-scale measures the skills of the individuals in analyzing verbal messages of the others. Individuals with social sensitivity care for 
social norms when they show social behaviors, and act in accordance with the environment they are in. Individuals with social sensitivity are under the influence of their emotions, and experience tension and inner conflicts more. However, they are very good listeners and observers (Riggio, 1986; Yüksel, 2004; Riggio \& Reichard, 2008; Kalafat \&Kincal, 2008).

6) Social control (SC) sub-scale measures the skills of the individuals to play social roles and to expose them as social entities. Individuals with developed social control are the ones with self-confidence and act in accordance with the social situations in any environment. Individuals with high social control ability are sympathetic, stable in terms of emotions, audacious, sincere, and comfortable people who have high-level self-confidence (Riggio, 1986; Yüksel, 2004; Riggio \& Reichard, 2008; Kalafat \&Kincal, 2008).

Each of the above-mentioned scales consisted of 15 items. The items in the scale were designed according to the 5-point likert answer key as " $1=$ this is unlike me", " $2=$ this is a little like me", " 3 = this is like me", " $4=$ this is quite like me" and " $5=$ this is exactly like me". The possible maximum score that may be received by a participant from the scale is 450 , and the minimum point is 90 . The maximum score that may be received in each sub-scale is 75 and the lowest is 15 . If a person received high points, it is accepted that the social skill levels of that person are high.

SSS, which was first developed by Riggio in 1986 and was revised in 1989, has been used by many academic studies both in our country and abroad. It was translated and adapted in Turkish by Galip Yüksel in 2004. The reliability and validity of the scale was proven many times. The Cronbach's Alpha value varied between $0.890-0.987$ in various studies. In other words, the scale is extremely reliable (Yüksel, 2004)

\section{FINDINGS}

The results obtained in the study are given in detail as follows.

\subsection{The Demographical Properties Of The Participants Of The Study}

A total of 20 people 10 of whom constituting the experimental group and 10 of whom constituted the control group participated in the study. The demographical characteristics of the participants in the groups are given briefly in Table 2 . 
Table 2: Demographic Characteristics Of Experimental Groups \& Control Groups

\begin{tabular}{|r|c|c|}
\hline & Experimental Group & Control Group \\
\hline Gender Female & 5 & \\
\hline Male & 5 & 5 \\
\hline Marital Status & & 5 \\
\hline Single & 2 & 2 \\
\hline Married & 8 & 8 \\
\hline Age & & 6 \\
\hline Les Than 50 & 6 & 4 \\
\hline More Than 50 & 4 & 6 \\
\hline Education Level & & 4 \\
\hline University & 8 & \\
\hline Post- Graduation & 2 & \\
\hline
\end{tabular}

As it is observed in table 2, five of the participants were female, and five were male in each group, i.e. In the experimental and the control group. 4 of them were single, and 16 of them were married. 12 of them were under the age of 50 , and the rest of them were over the age of 50. More than half of the participants were at least master's degree graduates.

\subsection{Social Skills Scale Pre-Training Results}

SSS distributed to the participants before the training started and the results were analyzed. The results are given in Table 3.

Table 3: Interpersonal Managenment Skill Pre-Training Results

\begin{tabular}{|l|c|c|c|c|}
\hline & \multicolumn{2}{|c|}{ Experimental Group } & \multicolumn{2}{c|}{ Control Group } \\
\hline & Mean & Std. Dev. & Mean & Std. Dev. \\
\hline Emotional Expressivity (Ee) & 52,7 & 6,8 & 51,2 & 7,6 \\
\hline Emotional Sensitivity (Es) & 56,1 & 5,9 & 54,1 & 5,6 \\
\hline Emotional Control (Ec) & 41,6 & 8,6 & 40,5 & 7,7 \\
\hline Social Expressivity (Se) & 56,4 & 3,7 & 56,2 & 5,6 \\
\hline Social Sensitivity (Ss) & 40,5 & 8,7 & 48,2 & 9,2 \\
\hline Social Control (Sc) & 59,8 & 3,6 & 57,7 & 7,3 \\
\hline Total & 307,1 & 15,3 & 308 & 19,3 \\
\hline
\end{tabular}

As it is observed in Table 3, the pretest social skills point average of the experimental and control group were 307.1 and 308, respectively; and the standard deviation was found to be 15.3 and 19.3, respectively. The results obtained from SSS may vary between 75 and 450 . As the point of the individual rises in the scale, the social skills level also rises. According to the points received in the pretest, it is possible to say that the social skills of the participants in the experimental and control group are at medium level. 
It is observed that the "social expressivity" and "social control" levels of the participants in the experimental and control group are higher than the other dimensions of their social skills. This shows us that the participants in the experimental and control group apply mostly verbal communication and adapt to social environments more easily. When the "social sensitivity" levels of the groups were compared with the other dimensions, it was observed that these values were extremely low. This shows that the participants in the experimental and control group are not under the influence of their emotions when establishing communications, and do not experience much tension and inner conflicts. At the end of the pretest analysis, it was observed that the participants had low average values in "emotional control" dimension. This shows that the participants cannot control their emotions in an easy manner, and cannot reflect their emotional status to their relations in an easy manner. It was determined that the "emotional expressivity" and "emotional sensitivity" levels of the participants were at medium level. Generally, it is possible to say that the average social skills levels of both groups were close to each other before the drama training. The Mann-Whitney $U$ test was used in order to test whether there were significant differences between the interpersonal management skill points of the experimental and control group before the drama training. The results of this analysis are summarized in Table 4.

Table 4: Mann Whitney U Test Results Before Drama Training

\begin{tabular}{|c|c|c|c|}
\hline & & Mean Rank & Sig. \\
\hline \multirow{2}{*}{ Emotional Expressivity (Ee) } & Experimental Gruop & 9,6 & \multirow{2}{*}{0,345} \\
\hline & Control Group & 10,4 & \\
\hline \multirow{2}{*}{ Emotional Sensitivity (Es) } & Experimental Gruop & 9,8 & \multirow{2}{*}{0,545} \\
\hline & Control Group & 10,2 & \\
\hline \multirow{2}{*}{ Emotional Control (Ec) } & Experimental Gruop & 9,6 & \multirow{2}{*}{0,348} \\
\hline & Control Group & 10,4 & \\
\hline \multirow{2}{*}{ Social Expressivity (Se) } & Experimental Gruop & 9,9 & \multirow[t]{2}{*}{0,833} \\
\hline & Control Group & 10,1 & \\
\hline \multirow{2}{*}{ Social Sensitivity (Ss) } & Experimental Gruop & 9,7 & \multirow{2}{*}{0,485} \\
\hline & Control Group & 10,3 & \\
\hline \multirow{2}{*}{ Social Control (Sc) } & Experimental Gruop & 9,5 & \multirow{2}{*}{0,305} \\
\hline & Control Group & 10,5 & \\
\hline \multirow{2}{*}{ Total } & Experimental Gruop & 9,7 & \multirow{2}{*}{0,488} \\
\hline & Control Group & 10,3 & \\
\hline
\end{tabular}

At the end of the Mann-Whitney U test, it was proven that the social skills of the participants in the experimental and control group were similar to each other before the drama training $(\mathrm{p}$ > $0.05)$. 


\subsection{Social Skills Scale Post-Training Results}

Social skills scale was distributed again to the participants after the training was over, and the results were analyzed. The results are given in Table 5.

Table 5: Interpersonal Management Skill Pre \& After Drama Training

\begin{tabular}{|l|c|c|c|c|c|c|}
\hline & \multicolumn{3}{|c|}{ Experimental Group } & \multicolumn{3}{c|}{ Control Group } \\
\hline & $\begin{array}{c}\text { Pre - } \\
\text { Education }\end{array}$ & $\begin{array}{c}\text { After } \\
\text { Education }\end{array}$ & $\begin{array}{c}\text { Change } \\
\mathbf{( \% )}\end{array}$ & $\begin{array}{c}\text { Pre - } \\
\text { Education }\end{array}$ & $\begin{array}{c}\text { After } \\
\text { Education }\end{array}$ & $\begin{array}{c}\text { Change } \\
(\%)\end{array}$ \\
\hline Emotional Expressivity (Ee) & 52,7 & 55,4 & 2,3 & 51,2 & 51,3 & 0,2 \\
\hline Emotional Sensitivity (Es) & 56,1 & 59,7 & 6,4 & 54,1 & 54,9 & 1,5 \\
\hline Emotional Control (Ec) & 41,6 & 46,9 & 12,7 & 40,5 & 40,8 & 0,7 \\
\hline Social Expressivity (Se) & 56,4 & 58,5 & 3 & 56,2 & 55,3 & $-1,6$ \\
\hline Social Sensitivity (Ss) & 40,5 & 42,3 & 4,4 & 48,2 & 48,7 & 1 \\
\hline Social Control (Sc) & 59,8 & 62,3 & 4,2 & 57,7 & 70,8 & 0,2 \\
\hline Total & 307,1 & 322,1 & 4,9 & 308 & 309,2 & 0,4 \\
\hline
\end{tabular}

The test results of the experimental and control group before and after the drama training are compared in Table 5. As it is observed in Table 5, according to the pretest and posttest results, the average social skills level development was $4.9 \%$ in the participants who were included in the experimental group; it was $0.04 \%$ in the participants who were included in the control group. It is assumed that this development in the social skill levels of the experimental group stems from the drama training provided for the participants in this group. It is observed that there is a slight increase in the social skill levels of the participants in the control group. It is assumed that the development observed in the control group is not significant. As it is observed in table 4 , there were increases in the social skills levels of the participants who were included in the experimental group after the drama training. When the changes in the sub-scales of the social skills were examined it was observed that there were serious differences between the experimental and control group. It was determined that the increases in the scale points of the experimental group were more than the increases in the sub-scales of the control group. It was also determined that the emotional control sub-scale points increased in the experimental group after the drama training, and the emotional expressivity increased at the lowest level. It was determined that the sub-scales of the experimental group showed an increase between $12.7 \%$ and $2.3 \%$. For this reason, the issue of whether the development was significant or not was investigated with the wilcoxon test, and the results are summarized in the Table 6 
Table 6: Wilcoxon Test Results Before And After Drama Training For Experimental Group

\begin{tabular}{|c|c|c|c|c|}
\hline & & & Mean Rank & Sig. \\
\hline \multirow{4}{*}{ Emotional Expressivity (Ee) } & Negative Ranks & 1 & 1,50 & \multirow{4}{*}{0,034} \\
\hline & Positive Ranks & 6 & 4,42 & \\
\hline & Ties & 3 & & \\
\hline & Total & 10 & & \\
\hline \multirow{4}{*}{ Emotional Sensitivity (Es) } & Negative Ranks & 1 & 7,00 & \multirow{4}{*}{0,036} \\
\hline & Positive Ranks & 9 & 5,33 & \\
\hline & Ties & 0 & & \\
\hline & Total & 10 & & \\
\hline \multirow{4}{*}{ Emotional Control (Ec) } & Negative Ranks & 0 & 0,00 & \multirow{4}{*}{0,008} \\
\hline & Positive Ranks & 9 & 5,00 & \\
\hline & Ties & 1 & & \\
\hline & Total & 10 & & \\
\hline \multirow{4}{*}{ Social Expressivity (Se) } & Negative Ranks & 2 & 2,00 & \multirow{4}{*}{0,048} \\
\hline & Positive Ranks & 6 & 5,33 & \\
\hline & Ties & 2 & & \\
\hline & Total & 10 & & \\
\hline \multirow{4}{*}{ Social Sensitivity (Ss) } & Negative Ranks & 2 & 1,90 & \multirow{4}{*}{0,043} \\
\hline & Positive Ranks & 7 & 5,29 & \\
\hline & Ties & 1 & & \\
\hline & Total & 10 & & \\
\hline \multirow{4}{*}{ Social Control (Sc) } & Negative Ranks & 1 & 2,00 & \multirow{4}{*}{0,024} \\
\hline & Positive Ranks & 7 & 4,86 & \\
\hline & Ties & 2 & & \\
\hline & Total & 10 & & \\
\hline \multirow{4}{*}{ Total } & Negative Ranks & 1 & 1,50 & \multirow{4}{*}{0,008} \\
\hline & Positive Ranks & 9 & 5,94 & \\
\hline & Ties & 0 & & \\
\hline & Total & 10 & & \\
\hline
\end{tabular}

At the end of the Wilcoxon test, significant differences were determined in the social skills and in all sub-skills of the participants who received drama training ( $p<0.05)$. It was determined that there were developments in the social skills of the participants in the experimental group after they received drama training. It was seen that the social skills score of 9 participants receiving the drama training was higher than the pre-training score. Only one participant did not receive a positive contribution from training. When the sub-dimensions of social skills are examined, it is seen that drama training has mostly developed emotional sensitivity dimension of social skill. It is also seen that social expressivity dimension is not affected too much by drama training compared to other dimensions. 
Table 7: Wilcoxon Test Results Before And After Drama Training For Control Group

\begin{tabular}{|c|c|c|c|c|}
\hline & & & Mean Rank & Sig. \\
\hline \multirow{4}{*}{ Emotional Expressivity (Ee) } & Negative Ranks & 3 & 3,50 & \multirow{4}{*}{0,230} \\
\hline & Positive Ranks & 4 & 4,20 & \\
\hline & Ties & 3 & & \\
\hline & Total & 10 & & \\
\hline \multirow{4}{*}{ Emotional Sensitivity (Es) } & Negative Ranks & 3 & 3,52 & \multirow{4}{*}{0,622} \\
\hline & Positive Ranks & 3 & 3,20 & \\
\hline & Ties & 4 & & \\
\hline & Total & 10 & & \\
\hline \multirow{4}{*}{ Emotional Control (Ec) } & Negative Ranks & 4 & 4,38 & \multirow{4}{*}{0,817} \\
\hline & Positive Ranks & 4 & 4,52 & \\
\hline & Ties & 2 & & \\
\hline & Total & 10 & & \\
\hline \multirow{4}{*}{ Social Expressivity (Se) } & Negative Ranks & 4 & 3,38 & \multirow{4}{*}{0,518} \\
\hline & Positive Ranks & 2 & 3,75 & \\
\hline & Ties & 4 & & \\
\hline & Total & 10 & & \\
\hline \multirow{4}{*}{ Social Sensitivity (Ss) } & Negative Ranks & 7 & 6,14 & \multirow{4}{*}{0,100} \\
\hline & Positive Ranks & 3 & 4,00 & \\
\hline & Ties & 0 & & \\
\hline & Total & 10 & & \\
\hline \multirow{4}{*}{ Social Control (Sc) } & Negative Ranks & 2 & 2,50 & \multirow{4}{*}{0,236} \\
\hline & Positive Ranks & 4 & 4,00 & \\
\hline & Ties & 4 & & \\
\hline & Total & 10 & & \\
\hline \multirow{4}{*}{ Total } & Negative Ranks & 3 & 3,50 & \multirow{4}{*}{0,122} \\
\hline & Positive Ranks & 4 & 4,83 & \\
\hline & Ties & 2 & & \\
\hline & Total & 10 & & \\
\hline
\end{tabular}

Negative Ranks; Score Before Training > Score After Training

Positive Ranks; Score Before Training < Score After Training

Ties; Score Before Training $=$ Score After Training

At the end of the Wilcoxon test, it was determined that there were no significant differences in social skills and in all the sub-dimensions of the social skills in the participants who did not receive drama training $(\mathrm{p}>0.05)$. It was determined that there were no signific ant differences in the social skills of the participants in the control group between first and second measurement.

In the last step of the analysis, the status of the experimental and control group after drama training was analyzed with the Mann-Whitney U test. The results of this analysis are given in Table 8. 
Table 8: Mann Whitney U Test Results After Drama Training

\begin{tabular}{|c|c|c|c|}
\hline & & Mean Rank & Sig. \\
\hline \multirow{2}{*}{ Emotional Expressivity (Ee) } & Experimental Gruop & 5,5 & \multirow{2}{*}{0,00} \\
\hline & Control Group & 14,5 & \\
\hline \multirow{2}{*}{ Emotional Sensitivity (Es) } & Experimental Gruop & 5,4 & \multirow{2}{*}{0,00} \\
\hline & Control Group & 14,6 & \\
\hline \multirow{2}{*}{ Emotional Control (Ec) } & Experimental Gruop & 4,2 & \multirow{2}{*}{0,00} \\
\hline & Control Group & 15,8 & \\
\hline \multirow{2}{*}{ Social Expressivity (Se) } & Experimental Gruop & 7,6 & \multirow{2}{*}{0,01} \\
\hline & Control Group & 12,4 & \\
\hline \multirow{2}{*}{ Social Sensitivity (Ss) } & Experimental Gruop & 6,5 & \multirow{2}{*}{0,00} \\
\hline & Control Group & 13,5 & \\
\hline \multirow{2}{*}{ Social Control (Sc) } & Experimental Gruop & 6,8 & \multirow{2}{*}{0,00} \\
\hline & Control Group & 13,2 & \\
\hline \multirow[b]{2}{*}{ Total } & Experimental Gruop & 8,2 & \multirow{2}{*}{0,01} \\
\hline & Control Group & 12,2 & \\
\hline
\end{tabular}

At the end of the Mann-Whitney U test, it was determined that there were meaningful differences in the social skills and in all the sub-dimensions of the social skills after the drama training $(\mathrm{p}<0.05)$. Developments were determined in the social skills and in all sub-dimensions of the social skills of the participants who received drama training in the experimental group. It was also determined that the participants in the experimental group showed the highest developments in emotional sensitivity and emotional control dimensions, and the lowest developments in social expressivity dimension.

\section{CONCLUSION \& DISCUSSION}

Drama training was a training technique that was applied heavily in the United States of America as of 1900s. At first, it was designed to train actors and actresses; however, especially as of 1980s, it became a training technique used for making the individuals develop their perceptions and comprehend environment in a better manner in many disciplines. This training technique, which aims to develop the perception level of individuals, ensured that individuals learnt in a more efficient manner and looked at their environment in a wider perspective.

In business world, drama training is applied mostly as role-playing for managers or employees. Because of the limited use of this training method, the outcomes are also limited. But in this study, the drama training was applied with a very wide application. Normally, drama training is provided as one or two days and covered only role-plays; however, in this study, drama training was provided in a multi-dimensional manner by a specialist trainer. 
The effects of drama training on interpersonal management skill of the managers were investigated in this study. 10 control and 10 experimental group participants, 20 participants in total, were included in the study. A quantitative examination was conducted on the participants and it was determined that the managers who received drama training improved their interpersonal management skill in a better manner than those who did not receive drama training. It was also determined that the interpersonal management skill of the participants who received drama training developed at a rate of $4.9 \%$.

The "Social Skills Scale", which was used in the study to determine the interpersonal management skill of the managers, consisted of six sub-dimensions. When each sub-dimension was examined one by one, it was observed that drama training was more influential in nonverbal communication dimensions. It was also determined that drama training caused increases at the highest level in emotional sensitivity and emotional control dimension, and at the lowest level in social expressivity dimension. The findings of this study are in parallel with other studies (Kara \& Çam, 2007; Okvuran, 2001; Önalan Akfirat, 2004; Önder, 2016) on drama education.

Although the research found that drama training had a significant effect on the interpersonal management skill of the managers, this effect did not seem to be very high. There are two reasons for this. First, managers take some time to get used to the drama method, especially because of their age. Therefore, the drama workshops to be applied to the managers should be organized considering the adaptation time of them. Better results will be achieved with longer-term training plans. In addition to this, some of the managers are not easy to accept this training method because of their prejudice. It is not easy to solve this problem. This prejudice can only be overcome by creative teaching techniques given at a young age. In short, it is possible to increase the degree of effect of education with extending the duration of education, preparing the selected group for education, and increasing the number of participants who are volunteering, willing and without prejudice against drama training.

Drama training have made significant contributions to managers to develop their interpersonal skills and their self-control skills. Managers should have the variables that make up social skills as a whole to build good relationships with their surroundings. For this reason, it is beneficial to put drama training to departments, which lead the candidates for managerial position, in the university. 
In today's competitive global world, it is crucial for managers to think differently from other managers and to produce creative solutions to the challenges they face. At this point, drama training has caused significant changes in managers' thinking and making decision styles. This change leads to changes in the manager's attitudes and behaviors and to increased creativity. By providing corporate level training programmes, companies can use drama training to influence the attitudes and motivations of both managers and employees and to improve their basic skills. In practice, it can be used to improve communication skills of both managers and employees, and solve complex business issues creatively. Drama training for companies can be an important tool for creativity in the business world. This advantage will provide competitive advantage to companies investing in this training. In other words, drama training is an important trainingal tool for both trainingal institutions and companies in today's world, where communication is regarded as one of the most important means of success.

This study has increased the need for studies that investigate the impact of drama education on the cognitive and emotional achievements of individuals on social skills and other skills. After this study, the effects of the drama training on the conceptual skill of managers can be investigated. In addition to this, the effect of drama training on company's financial performance, employee performance, and many organizational elements can be investigated.

As a conclusion, it is extremely important for managers, who spend more than $70 \%$ of their times in a day with communication to develop their interpersonal management skill, and drama training provides significant contributions to the development of these skills. 


\section{REFERENCES}

Akyol, A. K. (2003), "Drama Ve Dramanın Önemi", Türk Eğitim Bilimleri Dergisi, 1(2), 179-190.

Baransel, A. (1976), Çăgdaş Yönetimin Evrimsel Gelişimi. İstanbul: Avcıol Publishing

Baron, S., K. Harris And Et.Al. (2001), "Retail Theater: The Intended Effect Of The Performance", Journal Of Service Research, 4(2), 102-117.

Başkaya, Ö. (2000), "Dört Drama Liderinin Yaklasımlarına Genel Bir Bakıs Ve Yaratıcı Dramada Temel İlkeler", Türkiye 2. Drama Liderler Buluşması, Ankara: Olusum Tiyatrosu Ve Drama Atölyesi, 28-40

Beckwith, A. (2003), "Improving Business Performance - The Potential Of Arts İn Training" Industrial And Commercial Training, 35(5), Pp. 207-209. Doi:10.1108/00197850310487359

Corsun, D. L., C. A. Young, A. Mcmanus, A. And M. Erdem (2006), "Overcoming Managers'Perceptual Shortcuts Through İmprovisational Theater Games" Journal Of Management Development, 25(4), 298315. Doi:10.1108/02621710610655792

Cunha, M. P., K. Kamoche, And J.V. Cunda(1999), "Organizational Improvisation: What, When, How And Why", International Journal Of Management Review, 3(1), 299-341. Doi:10.111 1/1468-2370.00017

Daft, R. L. (2015), Management (12 Ed.), Cincinnati: South-Western College Publishing.

Dirim, A. (1999), Yaratıcı Drama, İstanbul: Esin Publishing.

Fisk, R. P. And S. J. Grove (1996), "Applications Of Impression Management And The Drama Metaphor İn Marketing: An Introduction", European Journal Of Marketing, 30(9), 6-12. Doi:10.1108/03090569610130061

Gardner, W. L. And B. J. Avolio (1998), "The Charismatic Relationship: A Dramaturgical Perspective", Academy Of Management Review, 23(1), 32-58. Doi:10.5465/A mr.1998.192958

Gibb, S. (2004), "Arts- Based Training İn Management Development: The Use Of Improvisational Theatre", Journal Of Management Development, 23(8), 741-750. Doi:10.1108/02621710410549594

Goddard, A. (1999), "Culture And Drama: The Role Of Financial Control Systems İn The Organisational Process İn Three Local Government Organisations", International Journal Of Public Sector Management, 12(6), 516-532. Doi:10.1108/09513559910301766

Goodwin, C. (1996), "Moving The Drama Into The Factory: The Contribution Of Metaphors To Services Research", European Journal Of Marketing, 30(9), 13-36. Doi:10.1108/03090569610130025

Gönen, M. And N. Uyar Dalkılıç (2010), Çocuk Eğitiminde Yaratıcı Drama, İstanbul: Epsilon.

Grahan-Hill, S. And A. J. Grimes (2001), "Dramatism As Method: The Promise Of Praxis", Journal Of Organizational Change Management, 14(3), 280-294. Doi:10.1108/09534810110394895

Güner, H. Ç. (2005), Yaratıcı Drama, İstanbul: Grena Publishing.

Häpfl, H. And G. Schreyägg (2004), "Theatre And Organization: Editorial Introduction", Organization Studies, 25(5), 691-704.

Harris, C. E. And R. L. Spiro (1981), "Training Implications Of Salesperson İnfluence Strategy", Journal Personal Selling \& Sales Management, 1(2), 10-17.

Harvey, A. (2001), "A Dramaturgical Analysis of Charismatic Leader Discourse", Journal Of Organizational Change Management, 14(3), 253-265. Doi:10.1108/09534810110394877

Higgs, N. (1993), "You Mean Like John Cleese?", Executive Development Volume, 6(4), 1-3.

Hsu, E. (1989), "Role-Event Gaming Simulation in Management Education: A Conceptual Framework And Review", Simulation \& Games, 20(4), 409-438. Doi:10.1177/104687818902000402

Kalafat, T. and R.Y. Kıncal (2008), "Üniversite Öğrencilerinin Bedensel Memnuniyeti Düzeyleri İle Sosyal Beceri Düzeyleri Arasındaki İlişkinin Belirlenmesi" Dokuz Eylül Üniversitesi Buca Eğitim Fakültesi Dergisi (23), 41-47 
Kara, Y. and F. Çam, F. (2007), "Yaratıı Drama Yönteminin Bazı Sosyal Becerilerin Kazandırılmas ın a Etkisi", Hacettepe Üniversitesi Eğitim Fakültesi Dergisi, 32, 145-155.

Koçel, T. (2015), İşletme Yöneticiliği, İstanbul: Beta Yayınları

Mayer, M. J. (2001), "Reflective Leadership Training in Practice Using Theatre As Representation", International Journal Of Leadership in Education, 4(2), 149-169.

Mirze, K. (2016), Business (6 Ed.), İstanbul: Literatür Publishing.

Moshavi, D. (2001), "Yes And...": Introducing Improvisational Theatre Techniques to The Management Classroom", Journal Of Management Education, 25(4), 437-449. Doi:10.1177/105256290102500408

Noe, R. A. (2009), İnsan Kaynaklarının Eğitimi ve Geliştirilmesi (C. Çetin, Trans..), İstanbul: Beta.

Okvuran, A. (2001), "Okulöncesi Dönemde Yaratıcı Drama", Çoluk Çocuk Dergisi, (3), 22-25.

O'neill, C. and A. Lambert (1982), Drama Structures: A Practical Handbook For Teachers, Portsmouth: Nh: Heinemann.

Önalan Akfirat, F. (2004), "Yaratıcı Dramanın İşitme Engellilerin Sosyal Becerilerinin Gelişimine Etkisi", Ankara Üniversitesi Eğitim Bilimleri Fakültesi Özel Eğitim Dergisi, 5(1), 9-22.

Önder, A. (2016), Yaşayarak Öğrenme İçin Eğitici Drama, İstanbul: Nobel Publishing.

Pearce, G. (2006), "The Advantages (Benefits) and Disadvantages (Weaknesses) Of Educational Drama: Perception Of Students Studying Marketing At University", The International Journal Of Management Education, 24(3).

Pearce, G. and J. Jackson (2006), "Today's Educational Drama - Planning For Tomorrow's Marketers", Marketing Intelligence \& Planning, 24(3), 218-232. Doi:10.1108/02634500610665691

Riggio, R. E. (1986), "Assessment Of Basic Social Skills", Journal Of Personality And Social Psychology, 51(3), 649-660.

Riggio, R. (1989), Social Skills Inventory. Palo Alto, Ca: Colsunting Psychologist Publishing.

Riggio, R. E. and R. J. Reichard. (2008), "The Emotional And Social İntelligences Of Effective Leadership: An Emotional and Social Skill Approach", Journal Of Managerial Psychology, 23(2), 169185 .

San, İ. (1991), Yaratıcı Drama, Ankara: Naturel Publishing.

Spolin, V. (1999), Improvisation For Theatre (3 Ed.), Illinois: North Western University Press.

Üstündağ, T. (1998), "Yaratıcı Drama Egitim Programının Ögeleri", Eğitim ve Bilim, 22(107), 28-35.

Vera, D. (2004), "Theatrical Improvisation: Lessons For Organizations", Organization Studies, 25(5), 727-479. Doi:10.1177/0170840604042412

Williams, J. A. and H. H. Anderson (2005), "Engaging Customers in Service Creation: A Theater Perspective", Journal Of Services Marketing, 19(1), 13-23. Doi:10.1108/08876040510579352

Yüksel, G. (2004), Sosyal Beceri Envanteri El Kitab1, Ankara: Asil Publishing. 